\title{
Production Banana Glucose Syrup with the $\alpha$-Amylase Supplementation
}

\section{Ashifa Cahyani Trisnaputri ${ }^{1}$, Nani Rahayu Usman ${ }^{2}$, Muhammad Al Mustawa $^{3}$ \& Abdul Mollah Jaya ${ }^{1}$}

${ }^{1}$ Department of Agronomy, Hasanuddin University, Makassar, South Sulawesi, Indonesia

${ }^{1}$ Department of Food Science and Technology, Hasanuddin University, Makassar, South Sulawesi, Indonesia

${ }^{3}$ Department of Chemistry, Hasanuddin University, Makassar, South Sulawesi, Indonesia

\begin{abstract}
Indonesia is one of the largest producing country of banana in the world, but approximately only 1,5 million tons were consumed. As one of the fruit which contains the highest carbohydrate, the overripe banana with the high contains of sugar has a potential to be developed as the raw material of glucose syrup. According to the research, the banana with a lot of bruise or black mark on the skin has 2,6\% strach, $33,6 \%$ reduction sugar, and $53,2 \%$ sucrose. In the making of banana glucose syrup, it will use $\alpha$-amylase to hydrolize the strach. Based on the reduction sugar analysis there are no significantly different between the addition of $0,25 \mathrm{ml}$ and $0,5 \mathrm{ml} \alpha$-amylase. The results has qualified the minimum standard of glucose percentage (min. $30 \%$ ) based on the reference SNI 01-2985-1992. The utilization of overripe bananas will greatly improve our glucose syrup production and ensure more of the banana waste can be saved in the future.
\end{abstract}

\section{Article History}

Received 13 June 2018

Accepted 12 July 2018

\section{Keyword}

$\alpha$-amylase

Banana

Glucose Syrup

Reduction Sugar

\section{Introduction}

Indonesia is one of the largest producing country of banana in the world. In 2016 Indonesia produced approximately 7,45 million tons of bananas, but approximately only 1,5 million tons were consumed (BPS, 2016). So, the surplus of banana probably will be wasted. Not only in Indonesia, but also on a global scale approximately millions of bananas end up or wasted along the supply chain. Routinately millions of edible bananas throw away everyday just because it has a minor bruise or black mark on the skin after it's overripe. In order to reduce the waste, the product which is made from banana as the raw material should be developed. As one of the fruit which contains the highest carbohydrate, the overripe banana with the high contains of sugar has a potential to be developed as the raw material of glucose syrup (high maltose syrup). 
Bananas has higher carbohydrate content than other fruits and overripe bananas with high sugar content has a potential as an alternative glucose syrup raw material. Naturally, total sugars in ripe fruits will increase due to changes in polysaccharides consisting of starch, pectin and hemicellulose into dissolved sugars. According to the research, the banana with a lot of bruise or black mark on the skin has 2,6\% strach, 33,6\% reduction sugar, and 53,2\% sucrose (Zhang et al., 2005).

Glucose syrup are now manufactured and used in many countries through out the world. Nowadays, glucose syrup is only produced from a variety of starch raw materials including, such as cassava, sago, rice, sorghum, wheat, corn, etc. (Vuilleumier, 1993; E.A. Borges da Silva, et al., 2006; Elkhalifa, et al., 2017). Producing glucose syrup by utilizing overripe banana as the raw material will greatly increase our glucose syrup production. The utilization of overripe bananas as a raw material for glucose syrup utilizes enzymatic reactions of $\alpha$-amylase enzymes used in the fructose syrup manufacturing industry to maximize natural starch in overripe bananas to produce quality high glucose syrup. The purpose of this research is to know the effectiveness of the addition of enzyme $\alpha$-amylase in the making of banana glucose syrup.

\section{Materials and Methods}

The materials that were used are banana (Musa paradisiaca L.) which have black bruise or mark on its skin (overripe) were used as the raw material. The enzyme used for the hydrolysis of starch was $\alpha$-amylase (Termamyl 120L), provided by Novozymes ${ }^{\circledR}$ (Denmark). Termamy $^{\circledR} 120 \mathrm{~L}$ is thermostable, produced by a selected strain of Bacillus licheniformis.

The first step is raw material preparation. Peel the banana $(500 \mathrm{~g})$ and cut it into small pieces. Puree the banana using food processor or blender. Combine the banana and $\alpha-$ amylase in a food processor or blender, and blend it until smooth. After the addition of $\alpha-$ amylase a liquefaction process will be happened.

Liquefaction is a process of dispersion of insoluble starch granules in aqueous solution followed by partial hydrolysis using thermostable amylases (Aiyer, 2005). The experimental design that were used is completely randomized design which consist of 1 factor (enzyme concentration) with 2 levels. Add $0,25 \mathrm{ml}$ (T1) and $0,5 \mathrm{ml}$ (T2) $\alpha$-amylase and put the banana puree at $90^{\circ} \mathrm{C}$ until the liquefication process is done. The extent of liquefaction was evaluated by the amount of reducing sugars produced, such as glucose, which represents a measure of reducing sugars present in the product as a percentage of the total dry substances (Lin et al., 2013).

After the liquefaction is done, the next step is purification process. In the purification process, 150 mesh and 400 mesh sieve were used. Agitate the sieves to allow the juice to pass through without giving any pressure on the pureed banana to prevent solids pass through the sieve along with the juice (liquid). After that, the liquid will be purified again with using microfiber filter.

The banana juice will be evaporated to reduce the moisture content up to $28,5-29,5 \%$ based on the reference SNI 01-2985-1992 (BSN, 1992). After the evaporation process, the viscosity will increase, so the the juice will become a syrup. The optimum temperature to put the syrup is $35^{\circ} \mathrm{C}$. In this temperature, the crystallization of dextrose will be prevented. The lower temperature will crystallize the syrup, so it could decrease the quality.

Before we do the reduction sugar test, the moisture content and total soluble solids must be determined based on the reference SNI 01-2985-1992. Moisture content of the syrup 
will be determined by using moisture analyzer. Moisture analyzer determines the moisture content of a sample with the loss on drying method and consists of a weighing and heating unit (infrared). Total soluble solids (\% Brix) content in the banana juice will be determined by using hand refraktometer. The sample was dripped into the refractometer prism. The temperature and the total soluble solids value will be observed. The total of reduction sugar will be determined based on (SNI-01-2892-1992) that use luff schoorl method.

In the microbiology test will be focused on Escherichia coli dan Staphylococcus aureus. The mikrobiology test will use standart plate count method to identify the contaminaton of E.coli and S. aureus. E.coli is one of negative gram bacteria which is classified into bacteria that can cause several digestion diseases, while $S$. aureus is one of positive gram bacteria that can influence the human antibody and cause several digestion diseases (Le Loir, 2003).

\section{Results and discussion}

Moisture is used as a quality factor for sugar syrup that will influence the time of storage. If the sugar syrup contain the high number of moisture content, the time of storage will decrease. Based on moisture analysis (Table 1) shows that the highest moisture content of syrup is $\mathrm{T}_{2}(35,97 \%)$ and the lowest moisture content of syrup is $\mathrm{T} 2_{1}(22,47 \%)$. Both the moisture content value between T1 and T2 are not significantly different and close enough with SNI 01-2985-1992 requirement. So, the moisture content has fullfilled the reference SNI 01-2985-1992.

Based on total soluble solids analysis (Table 2) shows that, the total soluble solids data (\%brix) are inversely proportional with the moisture content. The total soluble solids is the strach that were not hydrolized during the enzymatic process. The highest total soluble solids content is $\mathrm{T} 2_{1}(77,53 \%)$ and the lowest total soluble solids content is $\mathrm{T} 1_{2}(64,03 \%)$. Both the total soluble solids value between $\mathrm{T} 1$ and $\mathrm{T} 2$ are not significantly different and close enough with SNI 01-2985-1992 requirement. So, the moisture content has fullfilled the reference SNI 01-2985-1992.

Table 1. Moisture content analysis after adding $\alpha$-amylase

\begin{tabular}{ccc} 
Sample code & Moisture content (\%) & Total Soluble Solids(\%) \\
\hline $\mathrm{T} 1_{1}$ & 32,68 & 67,32 \\
$\mathrm{~T} 1_{2}$ & 35,97 & 64,03 \\
$\mathrm{~T} 1_{3}$ & 23,34 & 76,66 \\
\hline $\mathrm{T} 2_{1}$ & 22,47 & 77,53 \\
$\mathrm{~T} 2_{2}$ & 29,68 & 70,32 \\
$\mathrm{~T} 2_{3}$ & 29,73 & 70,27 \\
\hline
\end{tabular}

The reduction sugar analysis will show the potential of overripe banana as the raw material of high glucose syrup. Based on the reduction sugar analysis, after the enzymatic reaction by adding $\alpha$-amylase enzyme, the higest total of reduction sugar is $122_{3}(43,20 \%)$ and the lowest total of reduction sugar is $\mathrm{T} 22_{2}(34,99 \%)$. So, the are no significantly different between $\mathrm{T} 1$ and $\mathrm{T} 2$ reduction sugar. In the making of overripe banana glucose syrup, the natural enzymatic reaction during the ripening process that will hydrolyze the strach has to be increased with using $\alpha$-amylase, so the percentage of reduction sugar could be increased.

The ripe banana contain the high number of reduction sugar and sucrose but contain fewer strach. The percentage of strach will decrease during the increasing of the reduction sugar. The decreasing of strach is caused by enzymatic reaction that naturally happened 
during the ripening process (Zhang et al., 2005). Based on the calories analysis, banana glucose syrup contains $151,43 \mathrm{kcal}$ (Table 4). The calories that contain in banana glucose syrup is lower than sugar cane (364 kcal), aren sugar (368 kcal), coconut sugar (386 kcal) and another sweetener such as honey (294 kcal) (Rahmawati, 2017).

Tabel 3. Reduction sugar analysis after adding $\alpha$-amylase

\begin{tabular}{ccc} 
Sample code & Carbohydrate (\%) & Glucose (\%) \\
\hline $\mathrm{T} 1_{1}$ & 34,52 & 36,34 \\
$\mathrm{~T} 1_{2}$ & 36,11 & 38,01 \\
$\mathrm{~T} 1_{3}$ & 33,89 & 35,68 \\
\hline $\mathrm{T} 2_{1}$ & 34,92 & 36,76 \\
$\mathrm{~T} 2_{2}$ & 33,24 & 34,99 \\
$\mathrm{~T} 2_{3}$ & 41,04 & 43,20 \\
\hline
\end{tabular}

Table 4. Chemical composition of T1 sample (per $100 \mathrm{~g}$ )

\begin{tabular}{cc}
\hline Composition & Amount \\
\hline Carbohydrate & $36,36 \%$ \\
Protein & $1,25 \%$ \\
Fat & $0,11 \%$ \\
\hline Calories & $151,43 \mathrm{kcal}$ \\
\hline
\end{tabular}

Table 5. Microbiology test after adding $\alpha$-amylase

\begin{tabular}{cccc}
\hline Sample code & E. coli & S. aureus & Requirement \\
\hline $\mathrm{T} 1_{1}$ & - & - & $\checkmark$ \\
$\mathrm{T} 1_{2}$ & - & - & $\checkmark$ \\
$\mathrm{T} 1_{3}$ & - & - & $\checkmark$ \\
$\mathrm{T} 2_{1}$ & - & - & $\checkmark$ \\
$\mathrm{T} 2_{2}$ & - & - & $\checkmark$ \\
$\mathrm{T} 23$ & - & - & $\checkmark$ \\
\hline
\end{tabular}

$\checkmark$ : Has fulfilled the health requirement and SNI 01-2985-1992

Based on the microbiology test, all sample are not contamined by E.coli dan S.aureus (Table 5). So, the syrup has fulfilled the health requirement to be consumed. This result shows that there is no relationship between the addition of $\alpha$-amylase E.coli and S.aureus contamination. The contamination of E.coli and S.aureus will not happened as long as the hygenic of the raw material is kept during the production process.

\section{Conclusions}

In this research, overripe banana have a big potential to be the raw material in the making of glucose syrup. Based on the reduction sugar analysis are no significantly different between the addition $0,25 \mathrm{ml}$ and $0,5 \mathrm{ml} \alpha$-amylase. The contain of reduction sugar in banana glucose syrup has fulfilled the SNI 01-2985-1992 requirement (min. 30\%). 


\section{References}

Aiyer, Prasanna, V. 2005. Amylases and their Applications. African Journal of Biotechnology. 4(13):1525-1529.

Silva, E.A.B., Souza, A.A., Souza, S.G., Rodrigues, A.E. 2006. Analysis of the High-Fructose Syrup Production using Reactive SMB Technology. Chemical Engineering Journal. 118(3): 167-181.

Elkhalifa, E.A., Abdalla, N.K.A., Sarah \& Abdelkareem, A.M. 2017. Utilization of Sorghum (Feterita) Starch in Production of Fructose Syrup. International Journal of Food Science and Nutrition Engineering 2017, 7(4):70-74.

Le Loir Y, Florence, B. \& Michel G. 2003. Staphylococcus aureus and Food Poisoning. J Gen Mol Res, 2(1):63-76.

Lin, Q., Xiao, H., Liu, G. Q., Liu, Z., Li, L. \& Yu, F. 2013. Production of Maltose Syrup by Enzymatic Conversion of Rice Starch. Food and Bioprocess Technology, 6(1), 242-248.

Nurul, R., Budiarti, R.S. \& Harlis. Kajian Pembuatan Gula Cair Berbahan Dasar Kulit Singkong (Manihot utilissima Pohl.) dengan Pemanfaatan Bakteri Bacillus licheniformis. Universitas Jambi, Jambi.

Vuilleumier, S. 1993. Worldwide Production of High-Fructose Syrup and Crystalline Fructose. The American Journal of Clinical Nutrition. 58(1):733S-736S.

Zhang, P., Whistler, R.L., BeMiller, J.N. \& Hamake, B.R. 2005. Banana Starch: Production, Physicochemical Properties, and Digestibility : A Review. J Carbohy Polymers. 59: 443458. 